\title{
24-hour treatment of trichomoniasis with nimorazole (nitrimidazine)
}

\author{
A. C. H. CAMPBELL \\ Department of Venereology, Royal Northern Hospital, London
}

Recent studies (Moffett, McGill, Schofield, and Masterton, 1971; Cohen, 1971; Jelinek and Jones, 1971; McClean, 1972) have shown that nimorazole (formerly known as nitrimidazine) is an effective treatment for vaginal trichomoniasis and is comparable in this respect with metronidazole, although one investigation (Evans and Catterall, 1971) gave different results. A number of different treatment schedules have been proposed: some investigators have used daily doses for several days, whereas others have used large single doses. Long-term administration has the disadvantage that patients attending venereal disease clinics cannot be relied upon to take medication consistently. Moffett and others (1971), for example, estimate that only about half of their patients receiving oral therapy adhere to the schedule correctly. The difficulty may be compounded by the need for patients with other concomitant diseases, such as candidiasis, to take additional forms of treatment at the same time as the antitrichomonal drug.

On the other hand, a single large oral dose might be expected to produce a greater number of toxic effects than a more protracted course and might also be less effective. It was therefore decided to investigate two compromise solutions:

(1) Four tablets immediately followed by a further dose of four tablets at home (the ' $4+4$ ' schedule);

(2) Four tablets immediately and two further doses, each of four tablets, at home (the ' $4+4+4$ ' schedule).

\section{Schedules}

(1) THE ' $4+4$ ' TRIAL

Each patient received four $250 \mathrm{mg}$. tablets of nimorazole as soon as the diagnosis was made. Provided this first dose had been given before 4 p.m., the patient was instructed to take a further four tablets the same day before going to bed; if the first dose was given after

Received for publication July 8, 1972

Paper presented at the Jubilee Meeting of the M.S.S.V.D. at Glasgow, June 8 to 11,1972
4 p.m., the remaining tablets were to be taken the next morning.

(2) THE ' $4+4+4$ ' TRIAL

This was similar to the ' $4+4$ ' trial, except that after a first dose of four tablets the patients were instructed to take two further 4-tablet doses, one in the evening and one next morning; if the treatment was started after 4 p.m. on Day 1, the second dose was to be taken next morning (Day 2) and the third in the evening of Day 2.

\section{Patients and methods}

100 consecutive patients were treated in each trial. Their ages ranged from 14 to 51 years (Table I).

TABLE I Age distribution of 200 patients treated with nimorazole

\begin{tabular}{|c|c|}
\hline Age (yrs) & No. of patients \\
\hline $\begin{array}{l}14-19 \\
20-24 \\
25-29 \\
30-34 \\
35-39 \\
40-44 \\
45-49 \\
50-54\end{array}$ & $\begin{array}{r}11 \\
59 \\
60 \\
62 \\
6 \\
1 \\
0 \\
1\end{array}$ \\
\hline
\end{tabular}

The diagnosis of trichomoniasis was made by routine microscopy of vaginal secretions diluted in saline, and this was undertaken immediately after clinical examination by the doctor who was treating the patient concerned. Cultures were not used, partly because it seemed more valuable to investigate the efficacy of the treatments in the conditions actually obtaining in routine clinical work at the Royal Northern Hospital, and partly because previous experience (Woodcock, 1972) has shown that some cultural methods give results little better than those of simple microscopy.

Evidence of cure was likewise based on the results of microscopy. Patients were asked to return within 7 days and the tests were then repeated; a positive finding on this occasion was taken as evidence of 
'primary' failure. Further examinations were performed at each subsequent visit. Later recurrence within an arbitrary period of 2 months was regarded as evidence of relapse and is referred to here as 'secondary' failure, whether the patient admitted having had further sexual intercourse or not.

\section{Results (Table II)}

The follow-up ranged between 4 days and 3 months. Patients who failed to return for examination after their initial treatment were classed as defaulters, and were excluded from the trial.

(1) THE ' $4+4$ ' TRIAL

Of the original 100 patients, twenty defaulted after the initial treatment. Among the remaining eighty there were three primary failures ( 3.7 per cent.) and four secondary failures ( 5 per cent.); the total failure rate was thus 8.7 per cent., and the final cure rate $91 \cdot 3$ per cent.

(2) THE ' $4+4+4$ ' TRIAL

In this group there were 33 defaulters. Among the remaining 67 no primary failures occurred, and there were two secondary failures; the total failure rate was thus 2.9 per cent., and the final cure rate 97.1 per cent.

\section{Side-effects}

These were remarkably rare. One patient in the ' $4+4$ ' group vomited after the second dose, but otherwise no adverse effects were reported. No attempt was made to elicit complaints by direct questioning. This low incidence of side-effects agrees with that reported by other investigators using the standard regimen of $250 \mathrm{mg}$. twice daily for 6 days.

\section{Re-infections and relapses}

The distinction between re-infection and relapse is inevitably somewhat arbitrary. In many cases re-infection is due to the presence of trichomoniasis in the woman's sexual partner, and our policy is to treat the consorts of women with trichomoniasis wherever possible. In practice this is often difficult to achieve. In the ' $4+4$ ' trial twelve consorts, and in the ' $4+4+4$ ' trial seventeen consorts, were treated with metronidazole (one $200 \mathrm{mg}$. tablet three times daily for a week). In spite of these rather disappointing figures there were few re-infections (diagnosed later than 2 months after treatment) during the course of the trial-two occurred in the ' $4+4$ ' trial in addition to the four relapses already mentioned, and none in the ' $4+4+4$ ' trial.

\section{Associated conditions}

Gonorrhoea was found in 45 of the 200 patients (22.5 per cent.) and candidiasis in 53 (26.5 per cent.). Other conditions included genital warts (3), scabies (1), genital herpes (1), and cystitis (1). The association of trichomoniasis with gonorrhoea is noteworthy; the incidence of 22.5 per cent. of gonorrhoea in these patients compares with an overall incidence of gonorrhoea in new patients at our clinic of 13.2 per cent. in approximately the same period. The incidence of trichomoniasis at our clinic for the same period was 17.9 per cent. of new patients.

A further pointer towards the association between trichomoniasis and promiscuity is the number of previous infections. Of the 200 patients, 42 (21 per cent.) had had the disease at least once before, while one had had it seven times, another ten times, and a third no less than eleven times! These high reinfection rates are related to a tendency to default as soon as clinical relief is obtained.

\section{Conclusions}

Both schedules gave very satisfactory results and were almost entirely free from side-effects. The ' $4+4+4$ ' schedule was slightly the more effective of the two, and is to be preferred on this score.

Both schedules gave better results than were achieved by McClean (1972) and by Moffett and others (1971) with a standard 6-day regimen (combined primary and secondary failure rates of 18 and 16 per cent. respectively). However, Cohen (1971), who also used a 6-day regimen, found that 62 out of 63 patients were cured.

The effectiveness of the ' $4+4+4$ ' regimen seems to depend on a number of factors. In the first place, it produces blood levels of the drug which are little inferior to, but longer lasting than, those produced by a single large dose (Table III and Figure, opposite).

TABLE II Results of treatment with two-dose and three-dose schedules of nimorazole

\begin{tabular}{|c|c|c|c|c|c|c|c|c|c|c|}
\hline \multirow{3}{*}{ Trial } & \multirow{3}{*}{$\begin{array}{l}\text { No. of } \\
\text { Patients }\end{array}$} & \multirow{3}{*}{ Defaulters } & \multicolumn{6}{|c|}{ Failures } & & \\
\hline & & & \multicolumn{2}{|c|}{ Primary } & \multicolumn{2}{|c|}{ Secondary } & \multicolumn{2}{|c|}{ Total } & \multicolumn{2}{|c|}{ Total cures } \\
\hline & & & No. & Per cent. & No. & Per cent. & No. & Per cent. & No. & Per cent. \\
\hline $\begin{array}{l}' 4+4 ' \\
' 4+4+4 \text { ' }\end{array}$ & $\begin{array}{l}100 \\
100\end{array}$ & $\begin{array}{l}20 \\
33\end{array}$ & $\begin{array}{l}3 \\
0\end{array}$ & 3.7 & $\begin{array}{l}4 \\
2\end{array}$ & $\begin{array}{l}5 \\
2 \cdot 9\end{array}$ & $\begin{array}{l}7 \\
2\end{array}$ & $\begin{array}{l}8.7 \\
2 \cdot 9\end{array}$ & $\begin{array}{l}73 \\
65\end{array}$ & $\begin{array}{l}91 \cdot 3 \\
97 \cdot 0\end{array}$ \\
\hline
\end{tabular}


TABLE III Nimorazole serum levels in four healthy volunteers (mean body weight: $62 \mathrm{~kg}$.) after a single oral dose of $2 \mathrm{~g} .^{\star}$ Microbiological assay with $\mathrm{T}$. vaginalis in Bacto fluid thioglycollate medium with 10 per cent. horse serum

\begin{tabular}{|c|c|c|}
\hline \multirow[t]{2}{*}{ Subjects } & \multicolumn{2}{|c|}{ Serum levels $(\mu \mathrm{g} . / \mathrm{ml})}$. \\
\hline & at 2 hrs & at $24 \mathrm{hrs}$ \\
\hline $\begin{array}{l}1 \\
2 \\
3 \\
4\end{array}$ & $\begin{array}{l}40 \cdot 0 \\
32 \cdot 0 \\
32 \cdot 0 \\
24 \cdot 0\end{array}$ & $\begin{array}{l}0.9 \\
1.5 \\
2.2 \\
3.0\end{array}$ \\
\hline Averages & $32 \cdot 0$ & 1.9 \\
\hline
\end{tabular}

^Data provided by Carlo Erba (U.K.) Ltd.

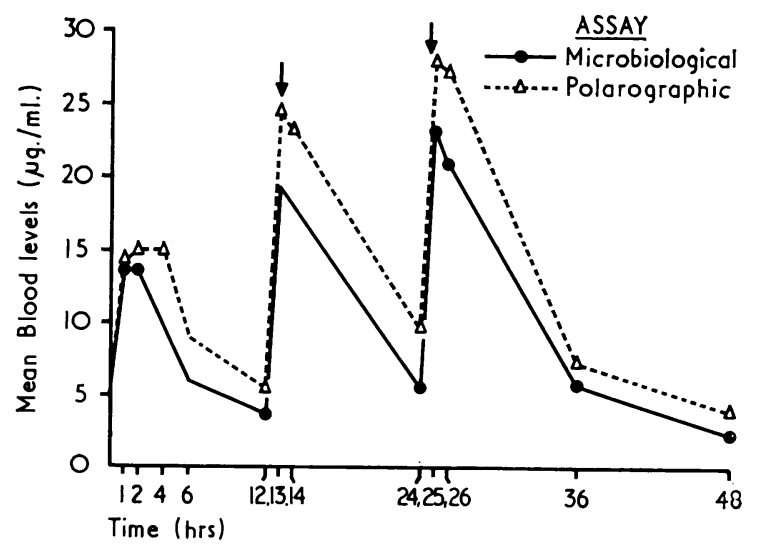

FI GURE Blood levels after nimorazole given orally in doses of $1 \mathrm{~g} .+1 \mathrm{~g} .+1 \mathrm{~g}$. at 12-hr intervals (mean of four subjects). Microbiological assay with $\mathrm{T}$. vaginalis in Bacto fluid thioglycollate medium with 10 per cent. horse serum.

(Data provided by Carlo Erba (U.K.) Ltd.)

Secondly, as mentioned above, patients cannot be relied on to continue treatment over a 6-day period, but it seems likely that fewer will fail to complete the relatively brief ' $4+4+4$ ' course.

\section{Summary}

Each of 100 patients with trichomoniasis received four $250 \mathrm{mg}$. tablets of nimorazole immediately, followed by a further four tablets later the same day or the next morning.

A second group of 100 patients was treated similarly, except that three doses were used, the first given immediately and two (more each of four tablets) were taken at home.

Both schedules gave highly satisfactory results; in the first group the failure rate among the eighty who re-attended was 8.7 per cent. (cure rate 91.3 per cent.), and in the second group, among 67 followedup, it was 2.9 per cent. (cure rate $97 \cdot 1$ per cent.). Side-effects were very rare. The ' $4+4+4$ ' schedule using nimorazole is recommended for the treatment of trichomoniasis.

I should like to express my thanks to Carlo Erba (U.K.) Ltd. for their assistance and for supplying the preparation of nimorazole (Naxogin) used in the trial; I should also like to thank Dr. G. Jelinek for his kind advice and help in the preparation of this paper.

\section{References}

Conen, L. (1971) Brit. F. vener. Dis., 47, 177

Evans, B. A., and Catterall, R. D. (1971) Brit. med. f., 4, 146

JELINEK, G., and JONES, J. P. (1971) VII International Congress of Chemotherapy, Prague, August, 1971

McClean, A. N. (1972) Brit. F. vener. Dis., 48, 69

Moffett, M., MCGill, M. I., Schofield, C. B. S., and MASTERTON, G. (1971) Ibid., 47, 173

Woodcock, K. R. (1972) Ibid., 48, 65

\section{Traitement de la trichomonase en 24 heures avec le nimorazole (nitrimidazine)}

SOMMAIRE

100 malades atteints de trichomonase reçurent chacun quatre comprimés de nimorazole d'emblée puis, de nouveau, quatre comprimés plus tard le même jour ou le lendemain matin. Un deuxième groupe de 100 malades fut traité de la même manière sauf que trois doses de quatre comprimés furent employées: la première d'emblée, les deux autres pour être prises à la maison.

Les deux schémas ont donné des résultats très satisfaisants; dans le premier groupe, le taux d'échec parmi les 80 malades revus fut de 8,7 pour cent (taux de guérison: 91,3 pour cent) et, dans le second groupe, parmi les 67 revus, le taux d'échec fut de 2,9 pour cent (taux de guérison: 97 pour cent). Les effets secondaires furent très rares. Le schéma ' $4+4+4$ ' de nimorazole est recommandé dans le traitement de la trichomonase. 